Texas A\&M University-San Antonio

Digital Commons @ Texas A\&M University- San Antonio

Criminology and Criminal Justice Faculty

Publications

College of Arts and Sciences

$12-2016$

\title{
Persona Non Grata: The Marginalization of Legal Scholarship in Criminology and Criminal Justice Journals
}

\author{
Brenda I. Rowe \\ Texas A\&M University-San Antonio, Brenda.Rowe@tamusa.edu \\ Wesley S. McCann \\ Washington State University \\ Craig Hemmens \\ Washington State University
}

Follow this and additional works at: https://digitalcommons.tamusa.edu/crim_faculty

Part of the Criminology and Criminal Justice Commons, and the Legal Writing and Research Commons

\section{Repository Citation}

Rowe, Brenda I.; McCann, Wesley S.; and Hemmens, Craig, "Persona Non Grata: The Marginalization of Legal Scholarship in Criminology and Criminal Justice Journals" (2016). Criminology and Criminal Justice Faculty Publications. 9.

https://digitalcommons.tamusa.edu/crim_faculty/9

This Article is brought to you for free and open access by the College of Arts and Sciences at Digital Commons @ Texas A\&M University- San Antonio. It has been accepted for inclusion in Criminology and Criminal Justice Faculty Publications by an authorized administrator of Digital Commons @ Texas A\&M University- San Antonio. For more information, please contact deirdre.mcdonald@tamusa.edu. 


\title{
Persona Non Grata:
}

\section{The Marginalization of Legal Scholarship in Criminology and Criminal Justice Journals}

\author{
Brenda I. Rowe* \\ Department of Social Sciences \\ Texas A \& M University - San Antonio \\ One University Way \\ San Antonio, TX 78224 \\ Email: Brenda.Rowe@tamusa.edu \\ Wesley S. McCann \\ Department of Criminal Justice and Criminology \\ Washington State University \\ 701 Johnson Tower \\ PO Box 644872 \\ Pullman, WA 99164-4872 \\ wmccann@wsu.edu \\ Phone: (509) 335-4031 \\ Craig Hemmens \\ Department of Criminal Justice and Criminology \\ Washington State University \\ 701 Johnson Tower \\ PO Box 644872 \\ Pullman, WA 99164-4872 \\ craig.hemmens@wsu.edu \\ Phone: (509) 335-4031
}

*Corresponding author

\begin{abstract}
About the Authors
Brenda I. Rowe, JD, PhD, is an assistant professor of Criminology at Texas A \& M University San Antonio. Her research interests include legal issues in criminal justice, criminal justice legislation, and police-prosecutor relationships.

Wesley S. McCann, M.A., is a doctoral student in the Department of Criminal Justice and Criminology at Washington State University. His research interests include legal issues in criminal justice, criminal law and procedure, terrorism, and counter-terrorism policy.

Craig Hemmens is chair and professor in the Department of Criminal Justice and Criminology at Washington State University. He has published more than 20 books and 200 articles and other writings on legal issues in criminal justice.
\end{abstract}




\title{
Persona Non Grata: The Marginalization of Legal Scholarship in Criminology and Criminal Justice Journals
}

\begin{abstract}
Recently, concern has been voiced within the academy regarding the marginalization of legal scholarship within the criminology and criminal justice (CCJ) discipline. Although conventional wisdom and anecdotal evidence indicate that it is difficult to get legal scholarship published in CCJ journals, there is a dearth of empirical evidence on the representation of legal scholarship in CCJ journals. The present study assesses the representation of legal scholarship in $20 \mathrm{CCJ}$ journals from 2005 through 2015, examining both trends over time and variation across journals. Findings indicate legal scholarship comprises a very small portion of articles published, there has been a steep decline in the number of legal articles published in recent years and the average number of legal articles per year is very low for nearly all of the journals in the sample. The implications of the marginalization of legal scholarship within the CCJ discipline are discussed.
\end{abstract}

Key words: legal research, bibliometrics, journals, criminal justice, scholarly publishing, qualitative research, law. 


\section{Persona Non Grata: The Marginalization of Legal Scholarship in Criminology and Criminal Justice Journals}

The position of law within the criminology and criminal justice (CCJ) discipline is no stranger to controversy, as evidenced by the debate concerning the role of JDs in CCJ departments (Engvall, 2007; Enriquez, 2007, 2008; Hemmens, 2008; Hunter, 2008; Myers, 2007) and disputes about whether law courses should even be part of the curriculum (Hemmens, 2015a, 2016; Russell, 1998; Smith, 1996). Recently, a growing chorus of voices has decried the marginalization of both legal scholarship and legal courses within the CCJ discipline and has made a compelling case that it is time to remedy this marginalization (Hemmens, 2015a, 2015b, 2016; Nolasco, del Carmen, Steinmetz, Vaughn, \& Spaic, 2015; Nolasco, Vaughn, \& del Carmen, 2010).

Given that in the absence of law there is no crime and no criminal justice system (Hemmens, 2015a; Nolasco et al., 2015), as the law plays a pivotal role in defining crime and delineating limits on the societal response to crime (Nolasco et al., 2015), one would think that law courses and legal scholarship would occupy a prominent place within the CCJ discipline. Yet legal courses are relegated to secondary status in CCJ departments, with law courses often offered as electives rather than as required courses (Bufkin, 2004; Griffin, Woodward, Nored, \& Johnson, 2013; Hemmens, 2015b, 2016; Lytle \& Travis, 2008), and legal scholarship occupies a place on the periphery of criminal justice scholarship due to misunderstandings about the nature of legal scholarship and its methodology which lead to the devaluation of this form of scholarship (Nolasco et al., 2010).

The marginalization of legal scholarship and legal courses within the CCJ discipline, while perhaps an unfortunate remnant of the discipline's attempts to establish itself as a legitimate academic discipline by distancing itself from subjects which were viewed as too 
practitioner-oriented and thus subject to the criticism of being vocational (Nolasco et al., 2015), is a hindrance to the discipline. There is a need for criminal justice scholars to conduct more legal research — both doctrinal legal research, which provides important information to criminal justice practitioners and policymakers, and legal research framed within a sociology of law perspective and conducted using legal and social science research methods, which can place the law in historical, social, and political context, as political scientists and sociologists do when studying legal issues (Hemmens, 2015a, 2016).

Criminal justice PhDs, at least if those scholars are educated in criminal justice departments committed to building legal competency in their graduates, are uniquely qualified to conduct research on legal issues in criminal justice informed by criminal justice concepts and theories and using both legal research and social science methodologies (Nolasco et al., 2015), which can constitute a form of mixed methods research when used in combination (Nolasco et al., 2010). Furthermore, criminal justice scholars who conduct research on legal issues are needed in order to provide criminal justice students with an education provided by instructors who are up-to-date on ever-changing legal issues critical to understanding the functioning of the criminal justice system (Hemmens, 2015b, 2016).

It is conventional wisdom among CCJ scholars that it is difficult to get legal scholarship published in CCJ journals. There is anecdotal evidence that legal scholars in CCJ face an obstacle in the form of some journal editors' lack of receptivity to legal scholarship (Hemmens, 2015b), and there is a growing discussion among CCJ scholars about the marginalization of legal scholarship within the CCJ discipline (Hemmens, 2015a, 2015b, 2016; Nolasco et al., 2015; Nolasco et al., 2010). However, there is a dearth of empirical evidence on the representation of legal scholarship in CCJ journals. This is due to a lack of empirical studies focusing specifically 
on legal scholarship articles published in CCJ journals combined with the tendency of studies examining the content of CCJ journals to use sampling criteria which exclude the forums in which legal scholarship is most likely to be found. This tendency is manifested in the following ways: (1) not including in the sample journals, such as Law and Society Review (LSR), which specialize in law-related topics (see e.g., Tewksbury, DeMichele, \& Miller, 2005); (2) omitting from the sample the portion of a journal in which legal manuscripts are published (see e.g., Tewksbury, Dabney, \& Copes, 2010); and (3) setting article inclusion criteria, such as only including empirical articles or articles which analyze data (often with no explicit explanation of how these terms are defined for purposes of that study), which may systematically exclude some types of legal scholarship (see e.g., Nelson, Wooditch, \& Gabbidon, 2014), even though arguably legal scholarship is empirical and court cases can be treated as data (Nolasco et al., 2010).

Given preliminary indications, albeit based on samples which are not ideal for studying legal scholarship in CCJ journals, that legal scholarship is rarely published in leading CCJ journals (Tewksbury et al., 2005) and that legal scholarship published in CCJ journals differs from other CCJ journal articles in several respects (Tewksbury et al., 2005), it is doubtful that findings of existing studies of the content of CCJ journals shed much light on the representation of legal scholarship in CCJ journals. The present study seeks to fill this void by conducting a systematic examination of legal scholarship published in CCJ journals which documents to what extent legal scholarship is represented in CCJ journals and how that representation varies across journals and over time.

\section{Studies of Content of CCJ Journals}

There are a number of empirical studies documenting the marginalization of subfields, such as white-collar crime (see e.g., McGurrin, Jarrell, Jahn, \& Cochrane, 2013) and 
international/comparative juvenile justice research (see e.g., Kim, Lin, \& Lambert, 2015), or methodologies, particularly qualitative methodologies (see e.g., Buckler, 2008; Tewksbury et al., 2010) such as ethnography (see e.g., Copes, Brown, \& Tewksbury, 2011), within the CCJ discipline. However, there are no similar systematic empirical studies specifically examining the representation of legal scholarship in CCJ journals.

There is a closely related body of literature, however, examining methodological aspects of studies published in CCJ journals (see e.g., Anderson Reinsmith-Jones, \& Mangels, 2011; Buckler, 2008; Copes et al., 2011; Crow \& Smykla, 2013; Kleck, Tark, \& Bellows, 2006; Tewksbury et al., 2010; Tewksbury et al., 2005). Such studies have found that articles published in CCJ journals disproportionately feature quantitative methods (Buckler, 2008; Crow and Smykla, 2013; Nolasco et al., 2010; Tewksbury et al., 2005; Tewksbury et al., 2010) and this holds true for both top-tier and lower-tier CCJ journals (Buckler, 2008), although lower-tier journals are slightly more likely than top-tier journals to publish qualitative (Buckler, 2008) and mixed methods studies (Crow \& Smykla, 2013). There is substantial variation among journals in the proportion of qualitative research articles (Tewksbury et al., 2010). Furthermore, qualitative research is much better represented in foreign CCJ journals than in American CCJ journals (Tewksbury et al., 2010). Research articles published in high-prestige CCJ journals rarely use ethnographic methods, and methodological and stylistic choices of these ethnographic studies vary by journal tier and article impact (Copes et al., 2011).

Most empirical studies published in leading CCJ journals are done at the individual level, employ a cross-sectional research design, and use secondary data (Kleck et al., 2006). The most frequently used data collection techniques are surveys, archival data, and official statistics pertaining to macro-level units (in that order; Kleck et al., 2006). The vast majority of studies 
published in top-ranked American CCJ journals rely on domestic data, 15\% of the studies use data which is more than a decade old and a fairly small proportion of those studies mention the age of the data as a limitation (Nelson et al., 2014). The gender composition of samples used in criminology research published in prominent sociology and criminology journals underrepresents females (Hughes, 2005). Use of triangulated methods is rare in articles published in leading CCJ journals (Anderson et al., 2011). Data collection methods vary between top-tier and regional journals, with a larger proportion of articles published in top-tier journals using official statistics or experiments and articles published in regional journals being more likely to use surveys, content analysis, and open-ended surveys (Crow \& Smykla, 2013).

Prior research has also examined topics featured in articles published in CCJ journals. Steinmetz, Schaefer, del Carmen, and Hemmens (2014) found that articles with criminology topical foci were more often featured in top-ranked CCJ journals in comparison to articles with criminal justice topical foci. Furthermore, criminology's predominance was more pronounced when journals which feature a great deal of legal scholarship (i.e., LSR and Journal of Criminal Law and Criminology [JCLC]) were excluded from the analysis, as law was considered a criminal justice topic (Steinmetz et al., 2014).

The study which has findings most directly speaking to the representation of legal scholarship in CCJ journals is Tewksbury et al.'s (2005) analysis of the methodological orientation of articles published in five top American CCJ journals (Criminology [CRIM], Justice Quarterly [JQ], Journal of Criminal Justice [JCJ], Criminal Justice and Behavior [CJB], and Journal of Research in Crime and Delinquency [JRCD]) from 1998 to 2002. Note, however, that given this study's focus, its findings regarding legal analysis articles likely pertain only to a subset of legal scholarship defined by a particular methodology, rather than encompassing the 
entirety of scholarship on legal issues in criminal justice (which can include quantitative research). Pertinent findings indicate that a legal research approach was rare, with legal analysis articles comprising only $1 \%$ of the articles (Tewksbury et al., 2005). In fact, three of the five journals examined $(C R I M, C J B$, and $J R C D)$ during this five-year time frame contained no legal analysis manuscripts (Tewksbury et al., 2005). Tewksbury et al. also found that legal analysis articles were the shortest, with an average page length of 16.1 pages, when compared to articles with other methodological orientations, which had average page lengths of 22 for quantitative, 23.9 for qualitative, and 28.3 for mixed methods.

\section{The Need for the Present Study}

There are a number of reasons to question whether the findings of existing studies of the content of CCJ journals provide adequate empirical evidence of the representation of legal scholarship in CCJ journals. First, there are no known recent systematic studies focusing specifically on the representation of legal scholarship in CCJ journals and employing a large sample (in terms of CCJ journals included and years included). This study seeks to remedy this deficiency by conducting a systematic empirical investigation of the representation of legal scholarship within CCJ journals using a large, inclusive sample.

Second, many of the existing studies of the content of CCJ journals use samples that exclude the forums where legal scholarship is most likely to be published, namely journals which specialize in law-related topics, such as $L S R$ (see e.g., Tewksbury et al., 2005), or the portion of a journal in which legal manuscripts are published, such as the section of JCLC which is devoted to criminal law (see e.g., Tewksbury et al. 2010). This study seeks to remedy this deficiency by: (1) not restricting the sample to journals or portions of journals that exclude legal research; and (2) including journals with a stated or demonstrated willingness to include legal research. 
Third, many of the existing studies of the content of CCJ journals use sample inclusion criteria with regard to article type, such as only including empirical articles or articles which analyze data (see e.g., Nelson et al., 2014), that likely systematically exclude doctrinal legal research. Such studies often fail to define terms in a transparent manner (see e.g., Nelson et al., 2014), which may leave the reader suspecting, especially given social scientists' misunderstanding of legal research methods (Nolasco et al., 2010), that doctrinal legal research was excluded from the sample (i.e., the study's authors did not consider doctrinal legal research empirical or did not view court cases as data, even though arguably one could do so; Nolasco et al., 2010) and that, as a result, the findings may not be applicable to legal scholarship. This study seeks to remedy this deficiency by using a large sample size with inclusion criteria with regard to article type that will not systematically exclude doctrinal legal research, which is an important subset of legal scholarship in criminal justice.

Fourth, the issues created by samples not suited to the examination of legal scholarship in CCJ journals are exacerbated by preliminary indications, albeit based on less than ideal samples, that legal scholarship is rarely published in leading CCJ journals (Tewksbury et al., 2005) and that legal scholarship published in CCJ journals differs from other CCJ journal articles in several respects (Tewksbury et al., 2005). For all of these reasons, the findings of existing studies of the content of CCJ journals may not shed much light on the representation of legal scholarship in CCJ journals.

There is a need for a systematic examination of the representation of legal scholarship in CCJ journals. The present study seeks to fill that void. This research can shed light on the current state of legal scholarship within CCJ journals, providing empirical data on the extent of the marginalization of legal scholarship within the discipline as well as how the representation of 
legal scholarship within CCJ journals varies across journals and over time. The present study will also draw comparisons between the representation of legal scholarship in CCJ journals and the representation of research on courts and sentencing in CCJ journals. This comparison is necessary due to the divergence of legal and criminal justice scholarship, and an overall lack of focus on laws that affect the criminal justice system. While many courts and sentencing articles have some legal element or component, conflating legal and courts and sentencing articles would exacerbate the underrepresentation of legal scholarship in our field. Put simply, understanding the presence-or lack thereof-of legal scholarship in CCJ journals over time should demonstrate to scholars how legal scholarship, despite its paramount importance for positive change in the criminal justice system, has been marginalized.

\section{Methods}

The sample is comprised of articles published from January 2005 through December 2015 (11 years) in 20 American CCJ journals. ${ }^{1}$ A list of top-ranked journals was compiled by combining the top 10 ranked journals from a study identifying the most prestigious journals in the CCJ discipline, based on ratings by American Society of Criminology (ASC) and Academy of Criminal Justice Sciences (ACJS) members (Sorensen, Snell, \& Rodriguez, 2006), and the top 10 ranked journals from a study identifying the highest impact journals in the CCJ discipline, based on citation analyses (Sorenson, 2009). This yielded 13 top-tier journals included in the sample: CRIM, JQ, JRCD, LSR, JCLC, Crime and Delinquency (CD), Criminology and Public Policy (CPP), Journal of Quantitative Criminology (JQC), Theoretical Criminology (TC), CJB, JCJ, Journal of Interpersonal Violence (JIV), and Prison Journal (PJ). Table 1 lists the journals in the sample, along with their rankings from the Sorenson et al. (2006) prestige study and the Sorenson (2009) impact study. 
In addition to these top-tier journals, seven other journals were added to the sample, based on either: (1) their focus and affiliation with either ACJS or ASC; or (2) their general prominence and focus on important topics within the field of criminal justice. ${ }^{2}$ These include: Police Quarterly (PQ), which is affiliated with the Police Section of ACJS; American Journal of Criminal Justice (AJCJ), which is affiliated with the ACJS Southern Region; Journal of Crime and Justice (JC\&J), which is affiliated with the ACJS Midwestern Region; Criminology, Criminal Justice, Law \& Society (CCJLS), which is affiliated with the western states in ASC and was formerly known as Western Criminology Review; Punishment \& Society (PS), which is a respected corrections journal; International Journal of Offender Therapy and Comparative Criminology (IJOTCC), which is a respected corrections journal; and Youth Violence and Juvenile Justice (YVJJ), which is a respected juvenile justice journal.

Regional journals were included in the sample because prior research has found variation in characteristics of articles published between top-tier and regional journals in terms of page length, research design, and data collection methods (Crow \& Smykla, 2013). The remaining journals were included in the sample because their focus helps to round out the topical focus of the journals included in the sample, given that there is an overrepresentation of criminology journals relative to criminal justice journals in the top-ranked journals. The addition of these journals to the sample ensures that journals which focus on important fields within criminal justice, such as policing, corrections, and juvenile justice, are included in the sample. Additionally, we sought to include as many journals as possible in the sample, in an effort to ensure our study did not overlook journals that might be more receptive to publishing legal 
articles_-prior studies often focus on either top-tier journals only or on a limited number of journals, or both.

The titles and abstracts of all articles published in these journals from 2005-2015 (an 11 year period) were reviewed in order to identify legal articles and courts and sentencing articles. If it was unclear from the abstract that the article would qualify either as a legal or courts and sentencing article, then the article was subjected to closer examination in order to confirm its status as either a legal article or courts and sentencing article. Articles were classified as legal articles if the primary focus of the article was: (1) the law, litigation, or legal decisions pertaining to criminal procedure, criminal law, or legal issues impacting the criminal justice system in general; or (2) how criminal law, criminal procedure, or criminal justice policy and legislation were related to society at large or other facets of the criminal justice system in part or in whole (police, courts, corrections, etc.). Either of these criteria can be satisfied when articles rely on or examine legal doctrine, legal theory, statutes, case law, or evaluations of laws and legislation. Thus, cases that may be solely focused on examining courts, but utilized a legal or doctrinal analysis of court decisions, can still be included as a legal article. Given that the focus of the present study is on legal scholarship in criminal justice, articles which had a topical or tangential focus on law or the relationship between law and society, but which were not primarily or solely focused on criminal procedure, criminal law, or legal issues affecting criminal justice were not counted as legal articles. In short, articles which focused on law but were not criminal justiceoriented were not coded. Many articles which contained a legal section or component that would otherwise constitute the article being legal in nature, yet were focused on criminal courts or sentencing holistically were coded as courts and sentencing articles. Note that this definition of legal scholarship is based on topical focus and is not restricted to any particular methodology. 
Thus legal scholarship may include a variety of methodologies including doctrinal legal analysis, content analysis, statutory comparison, and quantitative research. Numerous articles in Law and Society Review were not included in the count of legal articles because they pertained to law, but were not focused on criminal procedure, criminal law, or legal issues affecting criminal justice. For example, the article Why Do They Not Comply with the Law: Illegality and Semi-illegality of Rural-Urban Migrant Entrepreneurs in Beijing (He, 2005) focuses on the law. However, the primary focus of the article is on licensing and business regulations in China. None of these foci relates to the aforementioned elements of criminal law, criminal procedure, or laws influencing the criminal justice system. Appendix A provides more examples as to which articles would constitute legal articles under these criteria.

Articles were classified as courts and sentencing articles if the primary focus of the article was criminal courts or sentencing. This includes courtroom actors (judicial discretion, juror decision-making, prosecutorial discretion, or defense counsel and indigent defense), sentencing, the courtroom work group, or other aspects of courts and sentencing, which are not primarily or solely focused on the law. Many courts and sentencing articles contained some legal component due to their focus. However, distinguishing between legal and courts and sentencing articles is necessary and is achieved not just through the examination of the length of focus on either category, but is also dependent on what the main focus or purpose each article serves as a whole. For example, The Constitutionality of the Rome Statute of the International Criminal Court (Sheffer and Cox, 2008) deals with both courts and law. However, the primary focus of the article is legal, in that it examines the constitutionality of a law pertaining to the court. . Thus, if the primary focus of the article is on evaluating or altering criminal law, then the article would be legal despite its focus on courts or sentencing since the article is primarily concerned with a legal 
phenomenon. Similar to legal articles, many articles were also excluded from being counted to courts and sentencing articles if they had no relation to criminal justice or criminology. Nonetheless, if articles were even slightly related to criminal courts or the criminal justice system at large, they were included. Appendix A provides an example of this.

The sample included only articles, including articles reporting original research (widely conceived, thus including articles which analyze, through doctrinal legal research methods, qualitative, or quantitative methods, any form of data, including legal authorities such as cases and statutes), research notes, and literature reviews. Book reviews, editorial introductions, letters, miscellany, corrections, obituaries, acknowledgements, and announcements were excluded from the sample.

A codebook was developed to facilitate data gathering and coding for the variables under consideration, which include journal title, publication year, journal volume, journal issue, number of full articles in journal issue, number of legal articles in journal issue, and number of courts and sentencing articles in journal issue. Multiple authors independently coded all of the articles appearing in three years' worth of one journal in order to pilot test the codebook. Using this independent approach allows for the cross-validation of not only results, but also data collection and coding schemes via the content analysis. This was followed by a comparison of the results of this coding, a discussion of differences in coding and agreement on a common understanding to guide future coding decisions, and a revision of the coding instructions in the codebook to clarify coding for variables where differences in coding were identified. Throughout the coding process, if there was an issue with coding an article as either legal or courts and sentencing, multiple authors would collectively decide which category the article fell into and why based on both the codebook and magnitude of foci; henceforth establishing a rationale for 
the future coding of similarly-related articles. Once all data were collected, descriptive statistics, graphs, and charts were generated to analyze the data.

\section{Findings}

First, we assessed the overall representation of legal articles within the 20 target journals during the 11-year period and compared this with the representation of courts and sentencing articles. As shown in Table 2, during the 11-year period examined, while 7,593 articles were published in the 20 journals included in the sample, only 268 of those articles were legal articles and 420 of those articles were courts and sentencing articles.

-----Insert Table 2 About Here-----

-----Insert Figure 1 About Here-----

As shown in Figure 1, only 3.5\% of the articles published were legal articles and $5.5 \%$ of the articles published were courts and sentencing articles. Clearly, legal scholarship comprises a very small portion of the articles published in the 20 target journals from 2005 to 2015 .

Furthermore, research on courts and sentencing is also underrepresented, given that the courts are one of the three main components of the criminal justice system.

Next, we examined the trends in publication within the 20 target journals over the 11year period. Figure 2 depicts a comparison of the trends in number of all articles, number of legal articles, and number of courts and sentencing articles over time. Over the 11-year period, the overall number of articles published increased (from 571 articles in 2005 to 748 articles in 2015; see also Table 2). However, there is no similar increase in legal articles or in courts and sentencing articles.

-----Insert Figure 2 About Here-----

-----Insert Figure 3 About Here----- 
Figure 3 provides a closer look at the trends in the number of legal articles and the number of courts and sentencing articles published within the 20 target journals over the 11-year period. Clearly, there is a steep decline in the number of legal articles published over the last two years (declining from 30 legal articles in 2013 to 12 legal articles in 2015; see also Table 2).

Prior to that, there was minimal variation in the number of legal articles published (which generally stayed within the 20 to 30 articles range). In contrast, the trend in the number of courts and sentencing articles does not exhibit the same recent steep decline, but does exhibit some volatility over the years (with the number of courts and sentencing articles published generally staying within the 30 to 40 articles range, but with a dip below 30 articles in 2006 and notable spikes above 50 articles in 2007 and 2010; see also Table 2). ${ }^{3}$

Next, we looked at variation among journals in the extent to which legal articles and courts and sentencing articles are published. As shown in Table 3, there is great variation in the publication of legal articles across journals, with JCLC publishing far more legal articles than any other journal in the sample. Figure 4 illustrates that when comparing the number of legal articles, courts and sentencing articles, and other articles by journal, clearly the number of other articles dwarfs the number of legal articles and the number of courts and sentencing articles for all journals except for JCLC.

\section{-----Insert Table 3 About Here----- \\ -----Insert Figure 4 About Here-----}

Figure 5 provides a closer look at a comparison of the number of legal articles and the number of courts and sentencing articles by journal. One journal published far more legal articles than courts and sentencing articles: JCLC, which published 158 legal articles and 56 courts and sentencing articles (see also Table 3). Most of the journals published substantially more courts 
and sentencing articles than legal articles. Several journals published nearly as many legal articles as they did courts and sentencing articles, including: (1) AJCJ, which published 22 legal articles and 27 courts and sentencing articles; (2) PS, which published 15 legal articles and 21 courts and sentencing articles; and (3) PJ, which published seven legal articles and eight courts and sentencing articles (see also Table 3). Two journals published more legal articles than courts and sentencing articles, but did not publish very many of either type of article: (1) $T C$, which published six legal articles and four courts and sentencing articles; and (2) $P Q$, which published two legal articles and no courts and sentencing articles (see also Table 3).

\section{-----Insert Figure 5 About Here----- \\ -----Insert Table 4 About Here-----}

As shown in Table 4, the average number of legal articles per year is very low for nearly all of the journals in the sample (less than one article per year for 16 of the journals). JCLC is the only journal which has a substantial average number of legal articles per year (14.4). Three journals have an average number of legal articles per year which is between one and two: $L S R$, $A J C J$, and $P S$.

We also looked at each journal's contribution to the total legal articles published during the 11-year period. As shown in Figure 6, JCLC plays a dominant role in the publication of legal scholarship, publishing 59\% of the legal articles published. The next most prolific contributor to the publication of legal articles is AJCJ, which published $8.2 \%$ of the legal articles published, followed by $L S R$, which published $6 \%$ of the legal articles published, and $P S$, which published $5.6 \%$ of the legal articles published.

-----Insert Figure 6 About Here-----

-----Insert Table 5 About Here----- 
As shown in Table 5, we ranked the journals based on each journal's contribution to the total legal articles published during the 11-year period, percentage of the journal's articles which are legal articles, number of legal articles published, and total number of articles published. The journals are listed in Table 5 in the order of their ranking according to each journal's contribution to the total legal articles published. There is great similarity in the rankings based on each journal's contribution to the total legal articles published and the rankings based on number of legal articles published. JCLC ranks first in all measures of the publication of legal articles, but not in number of articles published. AJCJ, LSR, and PS round out the top four in the rankings based on all measures of the publication of legal articles. There is more variation in the rankings for percentage of journal's articles which are legal articles and total number of articles published, reflecting the fact that some journals rank higher in number of legal articles published and journal's contribution to the total legal articles published than one would expect based on the journal's percentage of articles which are legal articles due to the journal ranking highly in number of articles published (e.g., $J C J)$.

\section{Discussion and Conclusion}

Legal scholarship is marginalized within the CCJ discipline. In this sample of articles published in 20 journals from 2005 to 2015, legal articles comprise a very small portion (3.5\%) of the articles published. This finding is consistent with Tewksbury et al.'s (2005) finding that a legal research approach was rare (comprising $1 \%$ of articles published in five top CCJ journals during a 5-year period). The slightly higher proportion of legal articles found in the present study is not surprising considering: (1) the present study's use of a much larger (both in terms of journals and years) and more diverse sample (which is not limited solely to top-tier journals and also includes journals, such as $J C L C$ and $L S R$, which are specifically receptive to law-related 
topics); and (2) the difference in focus between the two studies, with the earlier study's focus on methodological aspects of journal articles making it likely that its findings regarding legal research pertain only to doctrinal legal research, whereas the present study defines legal scholarship more broadly to include a variety of methodological approaches to the study of legal issues in criminal justice. Courts and sentencing research is also underrepresented, comprising only $5.5 \%$ of articles published, which is surprising in light of the fact that the courts are one of the three main components of the criminal justice system.

Legal scholarship is becoming progressively more marginalized within the CCJ discipline in recent years. Despite the fact that the trend over the 11-year period was a substantial increase in the overall number of articles published, there was no similar increase in the number of legal articles published over that time period. Moreover, a steep decline over the last 2 years in the number of legal articles published has exacerbated the situation. This recent decline is influenced in part by a decrease in the number of issues published by JCLC, which typically publishes four issues per year, but published only three issues in 2014 and only one issue in 2015. This highlights the risk inherent in overreliance on JCLC as a forum for publishing legal scholarship within the CCJ discipline.

Publication of legal scholarship is largely concentrated in one journal, $J C L C$, and to a much lesser extent in a few other journals. The top four ranked journals in terms of both number of legal articles published and journal's contribution to total legal articles published by the 20 journals over the 11-year period are, in order, JCLC, AJCJ, LSR, and PS. JCLC plays a dominant role in the publication of legal scholarship, publishing $59 \%$ of all the legal articles published by the 20 journals over the 11-year period, which far exceeds the $8.2 \%$ of all legal articles published by $A J C J$, the second most prolific contributor to the publication of legal scholarship. With the 
notable exception of $J C L C$, the average number of legal articles per year is shockingly low for nearly all of the journals in the sample (less than one article for 16 of the journals and between one and two for the remaining three journals).

The marginalization of legal scholarship within the CCJ discipline has a number of implications. The dearth of legal scholarship in CCJ journals ignores the importance of law to criminal justice, which is surprising given the pivotal role the law plays in defining crime and delineating limits on the societal response to crime (Nolasco et al., 2015). When legal scholarship is largely absent from CCJ journals, this may contribute to a lack of knowledge of recent legal developments among CCJ faculty, who typically read CCJ journals to keep up to date on recent research within the discipline. This lack of knowledge, in turn, may hinder the ability of CCJ faculty to provide their students with the most current information regarding the laws impacting criminal justice.

Relegating scholarship on legal issues in criminal justice to student-edited law review journals, which typically are not peer-reviewed and are affiliated with a law school and run by law students (Hemmens, 2008; Hemmens, 2015b), poses several problems. Because publication in peer-reviewed journals within the CCJ discipline is expected of CCJ tenure-track faculty (Barranco, Jennings, May, \& Wells, 2016) and law review articles are generally treated as nonpeer-reviewed publications outside of the CCJ discipline in tenure and promotion evaluations (Hemmens, 2008; Hemmens, 2015b), upon observing the relative scarcity of legal scholarship in CCJ journals, CCJ scholars who could make substantial contributions by conducting research on legal issues in criminal justice may choose instead to conduct other research, such as research on a non-legal topic using multivariate analysis of a secondary data set, which is more in line with what commonly appears in CCJ journals (Kleck et al., 2006). This is problematic because CCJ 
scholars are uniquely positioned to conduct legal research which is informed by criminal justice concepts and theories (Nolasco et al., 2015). Legal scholarship published in student-edited law review journals is generally aimed at an audience of lawyers, and as such is not likely to be seen by CCJ scholars and criminal justice policymakers, and tends to be framed in terms of lawyers' concerns, rather than being situated in a criminal justice framework. Furthermore, when CCJ scholars are deterred from conducting research on legal issues in criminal justice because legal scholarship is not commonly published in CCJ journals and publishing in law reviews does not align with tenure and promotion criteria, CCJ faculty are less likely to be informed on recent developments in the law affecting criminal justice than they would be if they were actively conducting research in this area and this may impact the quality of education these faculty can provide to their students (Hemmens, 2015b).

The present study contributes to the growing discussion among CCJ scholars concerning the marginalization of legal scholarship within the CCJ discipline (Hemmens 2015a, 2015b; Nolasco et al., 2015; Nolasco et al., 2010) by providing empirical evidence of the representation of legal scholarship within CCJ journals and its variation across time and journals. Despite the importance of law to criminal justice, legal scholarship comprises a very small portion of the scholarship published in CCJ journals and is largely confined to one CCJ journal, JCLC. There is a scarcity of peer-reviewed publication outlets within the CCJ discipline for scholarship concerning legal issues in criminal justice (Hemmens, 2015b). In order to ameliorate this problem, several things need to occur. First, there is a need for more journals within the CCJ discipline which are devoted to publishing legal scholarship (Hemmens, 2015b). This would also require that legal or law review-type articles be peer-reviewed; thus incentivizing their promulgation. Second, there is a need for more editors who are receptive to publishing legal 
scholarship in existing CCJ journals (Hemmens, 2015b). Third, there is a need for peer-reviewers who understand the nature of legal research and its methodology (Nolasco et al., 2010).

While the present study provides empirical evidence of the scarcity of legal scholarship in CCJ journals, the volume of submissions of legal scholarship to CCJ journals is unknown. Given the conventional wisdom among CCJ scholars that it is very difficult to get legal scholarship published in CCJ journals and the anecdotal evidence of legal scholars in CCJ encountering both editors who are not receptive to legal scholarship (Hemmens, 2015b) and peer reviewers who misunderstand legal research methods and thus apply inappropriate criteria to legal manuscripts (Nolasco et al., 2010), it may be unlikely that the rarity of legal scholarship being published in CCJ journals is due to a low volume of submissions of legal scholarship to CCJ journals. However, the discussion regarding the status of legal scholarship in the CCJ discipline would benefit from empirical evidence regarding the volume of legal manuscripts submitted to CCJ journals. Future research should collect data on the actual volume of submissions of legal scholarship to CCJ journals, as well as employ surveys or interviews of journal editors and legal scholars in CCJ to collect data on journal editors' and peer reviewers' receptiveness to legal scholarship and legal scholars' experiences when submitting legal scholarship to CCJ journals and receiving peer reviews. Given the present study's focus on American CCJ journals, future research on the representation of legal scholarship within international CCJ journals is also warranted. 


\section{References}

Anderson, J. F., Reinsmith-Jones, K., \& Mangels, N. J. (2011). Need for triangulated methodologies in criminal justice and criminological research: Exploring legal techniques as an additional method. Criminal Justice Studies, 24(1), 83-103.

Barranco, R. E., Jennings, W. G., May, D. C., \& Wells, M. J. (2016). What journals are the most cited journals in criminology and criminal justice's "big three" journals? Journal of Criminal Justice Education, 27(1), 19-34.

Buckler, K. (2008). The quantitative/qualitative divide revisited: A study of published research, doctoral program curricula, and journal editor perceptions. Journal of Criminal Justice Education, 19(3), 383-403.

Bufkin, L. (2004). Criminology/criminal justice master's programs in the United States: Searching for commonalities. Journal of Criminal Justice Education, 15(2), 239-262.

Copes, H., Brown, A., \& Tewksbury, R. (2011). A content analysis of ethnographic research published in top criminology and criminal justice journals from 2000 to 2009. Journal of Criminal Justice Education, 22(3), 341-359.

Crow, M.S., \& Smykla, J. O. (2013). A mixed methods analysis of methodological orientation in national and regional criminology and criminal justice journals. Journal of Criminal Justice Education, 24(4), 536-555.

Engvall, R. P. (2007). Is it really “just a J.D.?” ACJS Today, 1, 5-6. Retrieved from http://www.acjs.org/pubs/167_666_3516.cfm

Enriquez, R. (2007). The vanishing JD-How ACJS Certification Ensures Extinction of the Species. Journal of Criminal Justice Education, 18(2), 254-260. 
Enriquez, R. (2008). Criminal justice faculty credentials: A response to Drs. Hemmens and Hunter. Journal of Criminal Justice Education, 19(2), 205-212.

Griffin, O. H., III, Woodward, V. H., Nored, L. S., \& Johnson, W. W. (2013). Meeting in the middle: A review of joint JD/PhD programs. American Journal of Criminal Justice, 38(3), 289-305.

Hemmens, C. (2008). Waist deep in the big muddy: The JD/PhD Debate in Criminal Justice Education. Journal of Criminal Justice Education, 19(1), 19-29.

Hemmens, C. (2015a). We (should) take care of our own: The role of law and lawyers in criminal justice and criminology programs. Justice Quarterly 32(5), 749-767.

Hemmens, C. (2015b, May). Why criminal procedure should matter to criminal justice departments. ACJS Today, 40(3), 21-25. Retrieved from http://www.acjs.org/pubs/167_666_3516.cfm

Hemmens, C. (2016). Teaching law and courts in criminal justice: Outside looking in. Journal of Criminal Justice Education 27(4), 497-508.

Hughes, L. A. (2005). The representation of females in criminological research. Women and criminal justice, 16(1-2), 1-28.

Hunter, R. D. (2008). Why we need certification standards in criminal justice education and what the impacts will be: A response to the concerns of JDs. Journal of Criminal Justice Education 19(2), 193-204.

Kim, B., Lin, W-C. A., \& Lambert, E. G. (2015). Comparative/international research on juvenile justice issues: A review of juvenile justice specialty journals. Journal of Criminal Justice Education, 26(4), 545-562. 
Kleck, G., Tark, J., \& Bellows, J. J. (2006). What methods are most frequently used in research in criminology and criminal justice? Journal of Criminal Justice, 34, 147-152.

Lytle, D. J., \& Travis, L. F., III (2008). Graduate education in criminology or criminal justice: Assessing course requirements. Journal of Criminal Justice Education, 19(3), 339-350.

McGurrin, D., Jarrell, M., Jahn, A., \& Cochrane, B. (2013). White collar crime representation in the criminological literature revisited, 2001-2010. Western Criminology Review, 14(2), 319. Available at http://westerncriminology.org/publications/western_criminology_review/

Myers, L. J. (2007). The search for the criminal justice educator. ACJS Today, 1, 5-6. Retrieved from http://www.acjs.org/pubs/167_666_3516.cfm

Nelson, M. S., Wooditch, A., \& Gabbidon, S. L. (2014). Is criminology out of date? A research note on the use of common types of data. Journal of Criminal Justice Education, 25(1), 16-33.

Nolasco, C. A. R. I., del Carmen, R. V., Steinmetz, K. F., Vaughn, M. S., \& Spaic, A. (2015). Building legal competency: Foundations for a more effective criminology and criminal justice discipline. Journal of Criminal Justice Education 26(3), 233-252.

Nolasco, C. A. R. I., Vaughn, M. S., \& del Carmen, R. V. (2010). Toward a new methodology for legal research in criminal justice. Journal of Criminal Justice Education, 21(1), 1-23.

Russell, S. (1998). In the ghetto: Legal studies in criminal justice programs. Journal of Criminal Justice Education, 9(2), 267-280.

Smith, C. (1996). Teaching the irrelevance of law on criminal procedure. Journal of Criminal Justice Education 7(1), 45-58. 
Steinmetz, K. F., Schaefer, B. P., del Carmen, R. V., \& Hemmens, C. (2014). Assessing the Boundaries Between Criminal Justice and Criminology. Criminal Justice Review, 39(4), $357-376$.

Sorensen, J. R. (2009). An assessment of the relative impact of criminal justice and criminology journals. Journal of Criminal Justice, 37, 505-511.

Sorensen, J., Snell, C., \& Rodriguez, J. J. (2006). An assessment of criminal justice and criminology journal prestige. Journal of Criminal Justice Education, 17(2), 297-322.

Tewksbury, R., Dabney, D., \& Copes, H. (2010). The prominence of qualitative research in criminology and criminal justice scholarship. Journal of Criminal Justice Education, 21(4), 391-411.

Tewksbury, R., DeMichele, M. T., Miller, J. M. (2005). Methodological orientations of articles appearing in criminal justice's top journals: Who publishes what and where. Journal of Criminal Justice Education, 16(2), 265-279.

\section{Footnotes}

${ }^{1}$ Data collection ended in December 2015 and thus any backdated journal issues which are part of a journal's 2015 issues, but which were actually published after the year 2015 are excluded from the sample.

${ }^{2}$ Criminal Law Bulletin was not included in the sample because its target audience is law professors, rather than academics in CCJ. Additionally, it does not enjoy in CCJ the same prominent status it has within the legal discipline $\left(2^{\text {nd }}\right.$ among criminal procedure-focused journals), as evidenced by its rankings of $62^{\text {nd }}$ and $50^{\text {th }}$, respectively, in the Sorensen (2009) impact study and the Sorensen et al. (2006) prestige study, and it is not affiliated with either 
ACJS or ASC. The current editor of the Criminal Law Bulletin hopes to improve its ranking among CCJ journals.

${ }^{3}$ An examination of the percentage of articles published which are legal articles and the percentage of articles published which are courts and sentencing articles over time reveals similar trends over the 11-year period. 


\section{Tables}

Table 1

Journals in Sample

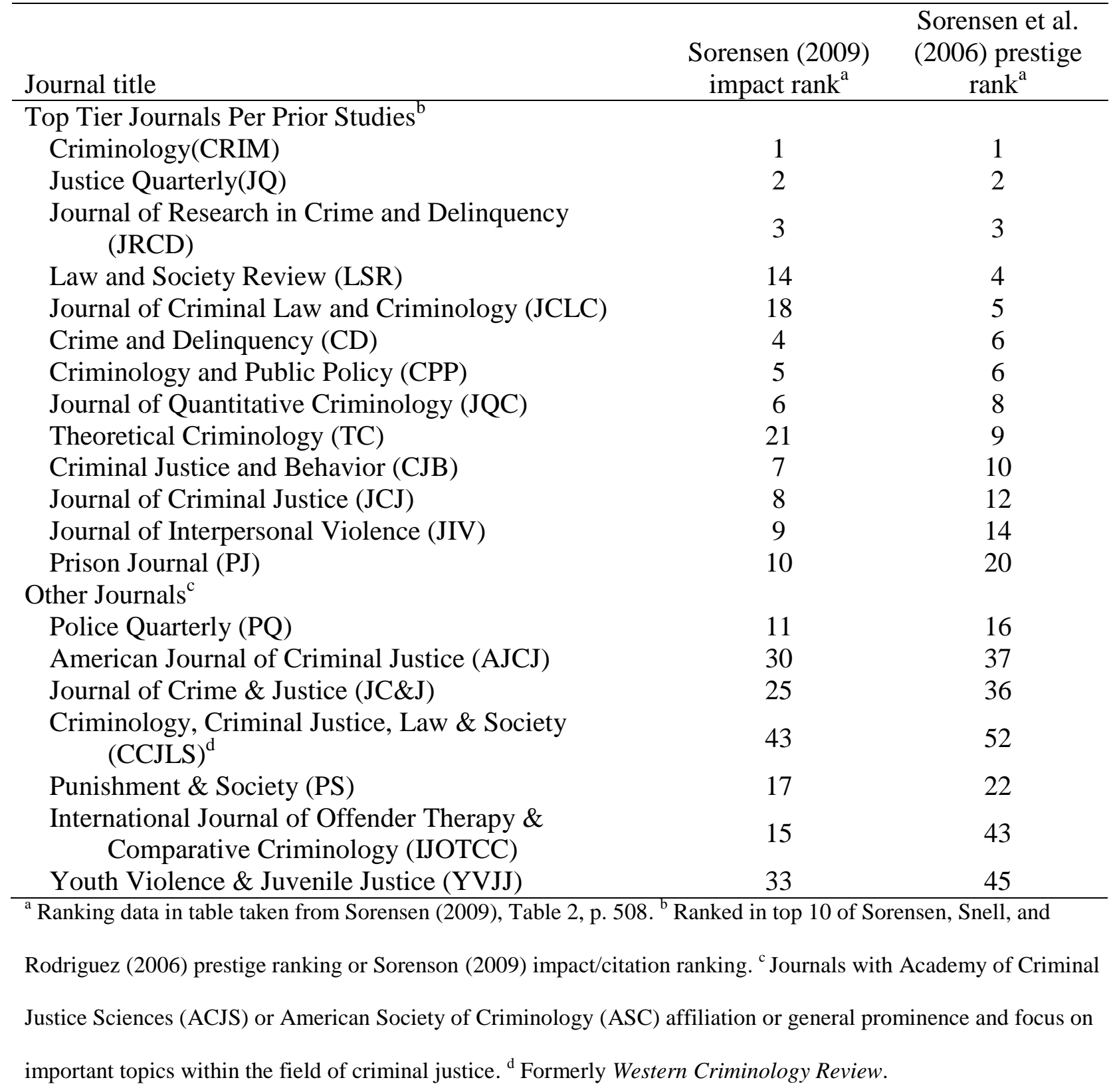


PERSONA NON GRATA

Table 2

Comparison of Publication of Legal Articles and Courts and Sentencing Articles Over Time

\begin{tabular}{|c|c|c|c|c|c|}
\hline \multirow[b]{2}{*}{ Year } & \multicolumn{3}{|c|}{ Number of articles } & \multicolumn{2}{|c|}{$\%$ of articles } \\
\hline & All & Legal & $\begin{array}{l}\text { Courts and } \\
\text { sentencing }\end{array}$ & Legal & $\begin{array}{l}\text { Courts and } \\
\text { sentencing }\end{array}$ \\
\hline 2005 & 571 & 25 & 38 & 4.38 & 6.65 \\
\hline 2006 & 548 & 24 & 26 & 4.38 & 4.74 \\
\hline 2007 & 625 & 28 & 53 & 4.48 & 8.48 \\
\hline 2008 & 608 & 22 & 35 & 3.62 & 5.76 \\
\hline 2009 & 636 & 25 & 30 & 3.93 & 4.72 \\
\hline 2010 & 746 & 21 & 57 & 2.82 & 7.64 \\
\hline 2011 & 776 & 26 & 38 & 3.35 & 4.90 \\
\hline 2012 & 781 & 30 & 34 & 3.84 & 4.35 \\
\hline 2013 & 771 & 30 & 37 & 3.89 & 4.80 \\
\hline 2014 & 783 & 25 & 38 & 3.19 & 4.85 \\
\hline 2015 & 748 & 12 & 34 & 1.60 & 4.55 \\
\hline All & 7593 & 268 & 420 & 3.53 & 5.53 \\
\hline
\end{tabular}




\section{PERSONA NON GRATA}

Table 3

Comparison of Publication of Legal Articles and Courts and Sentencing Articles by Journal

\begin{tabular}{|c|c|c|c|c|c|c|}
\hline \multirow[b]{2}{*}{ Journal } & \multicolumn{3}{|c|}{ Number of articles } & \multicolumn{2}{|c|}{$\%$ of articles } & \multirow[b]{2}{*}{$\%$ of all legal ${ }^{\mathrm{b}}$} \\
\hline & All & Legal & $\begin{array}{l}\text { Courts and } \\
\text { sentencing }\end{array}$ & Legal $^{\mathrm{a}}$ & $\begin{array}{l}\text { Courts and } \\
\text { sentencing }\end{array}$ & \\
\hline CRIM & 323 & 1 & 25 & 0.31 & 7.74 & 0.37 \\
\hline JQ & 348 & 6 & 42 & 1.72 & 12.07 & 2.24 \\
\hline JRCD & 239 & 1 & 11 & 0.42 & 4.60 & 0.37 \\
\hline LSR & 283 & 16 & 28 & 5.65 & 9.89 & 5.97 \\
\hline JCLC & 282 & 158 & 56 & 56.03 & 19.86 & 58.96 \\
\hline $\mathrm{CD}$ & 381 & 2 & 42 & 0.52 & 11.02 & 0.75 \\
\hline CPP & 170 & 3 & 21 & 1.76 & 12.35 & 1.12 \\
\hline JQC & 248 & 0 & 16 & 0.00 & 6.45 & 0.00 \\
\hline $\mathrm{TC}$ & 244 & 6 & 4 & 2.46 & 1.64 & 2.24 \\
\hline CJB & 754 & 4 & 23 & 0.53 & 3.05 & 1.49 \\
\hline $\mathrm{JCJ}$ & 706 & 7 & 35 & 0.99 & 4.96 & 2.61 \\
\hline YVJJ & 226 & 1 & 16 & 0.44 & 7.08 & 0.37 \\
\hline JIV & 1477 & 3 & 18 & 0.20 & 1.22 & 1.12 \\
\hline PJ & 271 & 7 & 8 & 2.58 & 2.95 & 2.61 \\
\hline PQ & 217 & 2 & 0 & 0.92 & 0.00 & 0.75 \\
\hline AJCJ & 285 & 22 & 27 & 7.72 & 9.47 & 8.21 \\
\hline $\mathrm{JC} \& \mathrm{~J}$ & 179 & 5 & 11 & 2.79 & 6.15 & 1.87 \\
\hline CCJLS & 111 & 2 & 4 & 1.80 & 3.60 & 0.75 \\
\hline PS & 221 & 15 & 21 & 6.79 & 9.50 & 5.60 \\
\hline IJOTCC & 628 & 7 & 12 & 1.11 & 1.91 & 2.61 \\
\hline All & 7593 & 268 & 420 & 3.53 & 5.53 & \\
\hline
\end{tabular}

Note. CRIM = Criminology; JQ = Justice Quarterly; JRCD = Journal of Research in Crime and Delinquency; LSR $=$ Law and Society Review $;$ JCLC $=$ Journal of Criminal Law and Criminology; $\mathrm{CD}=$ Crime and Delinquency; $\mathrm{CPP}=$ Criminology and Public Policy; JQC $=$ Journal of Quantitative Criminology; TC $=$ Theoretical Criminology; CJB = Criminal Justice and Behavior; JCJ = Journal of Criminal Justice; YVJJ = Youth Violence and Juvenile Justice; JIV = Journal of Interpersonal Violence; PJ = Prison Journal; PQ = Police Quarterly; AJCJ = American Journal of Criminal Justice; JC\&J = Journal of Crime and Justice; CCJLS = Criminology, Criminal Justice, Law \& Society (formerly Western Criminology Review); PS = Punishment \& Society; IJOTCC = International Journal of Offender Therapy and Comparative Criminology.

${ }^{a}$ Percentage of journal's articles which are legal articles. ${ }^{b}$ Percentage of total legal articles (published by all journals) which are published by this journal. 
PERSONA NON GRATA

Table 4

Average Number of Articles Per Year by Journal and Article Type

\begin{tabular}{|c|c|c|c|}
\hline \multirow[b]{2}{*}{ Journal } & \multicolumn{3}{|c|}{ Average number of articles per year } \\
\hline & All & Legal & Courts and sentencing \\
\hline CRIM & 29.36 & 0.09 & 2.27 \\
\hline JQ & 31.64 & 0.55 & 3.82 \\
\hline JRCD & 21.73 & 0.09 & 1.00 \\
\hline LSR & 25.73 & 1.45 & 2.55 \\
\hline JCLC & 25.64 & 14.36 & 5.09 \\
\hline CD & 34.64 & 0.18 & 3.82 \\
\hline CPP & 15.45 & 0.27 & 1.91 \\
\hline JQC & 22.55 & 0.00 & 1.45 \\
\hline TC & 22.18 & 0.55 & 0.36 \\
\hline CJB & 68.55 & 0.36 & 2.09 \\
\hline JCJ & 64.18 & 0.64 & 3.18 \\
\hline YVJJ & 20.55 & 0.09 & 1.45 \\
\hline JIV & 134.27 & 0.27 & 1.64 \\
\hline PJ & 24.64 & 0.64 & 0.73 \\
\hline PQ & 19.73 & 0.18 & 0.00 \\
\hline AJCJ & 25.91 & 2.00 & 2.45 \\
\hline $\mathrm{JC} \& \mathrm{~J}$ & 15.45 & 0.27 & 1.91 \\
\hline CCJLS & 10.09 & 0.18 & 0.36 \\
\hline PS & 20.09 & 1.36 & 1.91 \\
\hline IJOTCC & 57.09 & 0.64 & 1.09 \\
\hline
\end{tabular}

Note. CRIM = Criminology; JQ = Justice Quarterly; JRCD = Journal of Research in Crime and Delinquency; LSR = Law and Society Review; JCLC = Journal of Criminal Law and Criminology; $\mathrm{CD}=$ Crime and Delinquency; $\mathrm{CPP}=$ Criminology and Public Policy; JQC = Journal of Quantitative Criminology; $\mathrm{TC}=$ Theoretical Criminology; $\mathrm{CJB}=$ Criminal Justice and Behavior; JCJ = Journal of Criminal Justice; YVJJ = Youth Violence and Juvenile Justice; $\mathrm{JIV}=$ Journal of Interpersonal Violence; $\mathrm{PJ}=$ Prison Journal; $\mathrm{PQ}=$ Police Quarterly; AJCJ = American Journal of Criminal Justice; JC\&J = Journal of Crime and Justice; CCJLS = Criminology, Criminal Justice, Law \& Society (formerly Western Criminology Review); PS = Punishment \& Society; IJOTCC = International Journal of Offender Therapy and Comparative Criminology. 
Table 5

Comparison of Journal Rankings by Various Measures of Publication of Legal Articles and by Total Articles Published

\begin{tabular}{|c|c|c|c|c|}
\hline \multirow[b]{2}{*}{ Journal } & \multicolumn{4}{|c|}{ Journal ranking by } \\
\hline & $\%$ of all legal ${ }^{\mathrm{a}}$ & $\begin{array}{c}\text { \% of articles } \\
\text { legal }^{\mathrm{b}}\end{array}$ & $\begin{array}{c}\text { Number of legal } \\
\text { articles }\end{array}$ & $\begin{array}{c}\text { Number of } \\
\text { articles }\end{array}$ \\
\hline JCLC & 1 & 1 & 1 & 10 \\
\hline AJCJ & 2 & 2 & 2 & 8 \\
\hline LSR & 3 & 4 & 3 & 9 \\
\hline PS & 4 & 3 & 4 & 16 \\
\hline JCJ & 5 & 12 & 5 & 3 \\
\hline PJ & 5 & 6 & 5 & 11 \\
\hline IJOTCC & 5 & 11 & 5 & 4 \\
\hline $\mathrm{JQ}$ & 8 & 10 & 8 & 6 \\
\hline $\mathrm{TC}$ & 8 & 7 & 8 & 13 \\
\hline $\mathrm{JC} \& \mathrm{~J}$ & 10 & 5 & 10 & 18 \\
\hline $\mathrm{CJB}$ & 11 & 14 & 11 & 2 \\
\hline $\mathrm{CPP}$ & 12 & 9 & 12 & 19 \\
\hline JIV & 12 & 19 & 12 & 1 \\
\hline $\mathrm{CD}$ & 14 & 15 & 14 & 5 \\
\hline PQ & 14 & 13 & 14 & 17 \\
\hline CCJLS & 14 & 8 & 14 & 20 \\
\hline CRIM & 17 & 18 & 17 & 7 \\
\hline JRCD & 17 & 17 & 17 & 14 \\
\hline YVJJ & 17 & 16 & 17 & 15 \\
\hline JQC & 20 & 20 & 20 & 12 \\
\hline
\end{tabular}

Note. Journals are listed in rank order by percentage of all legal articles published. CRIM = Criminology; $\mathrm{JQ}=$ Justice Quarterly; JRCD = Journal of Research in Crime and Delinquency; LSR = Law and Society Review; JCLC = Journal of Criminal Law and Criminology; $\mathrm{CD}=$ Crime and Delinquency; $\mathrm{CPP}=$ Criminology and Public Policy; JQC = Journal of Quantitative Criminology; $\mathrm{TC}=$ Theoretical Criminology; $\mathrm{CJB}=$ Criminal Justice and Behavior; JCJ = Journal of Criminal Justice; YVJJ = Youth Violence and Juvenile Justice; JIV = Journal of Interpersonal Violence; PJ = Prison Journal; PQ = Police Quarterly; AJCJ = American Journal of Criminal Justice; JC\&J = Journal of Crime and Justice; CCJLS = Criminology, Criminal Justice, Law \& Society (formerly Western Criminology Review); PS = Punishment \& Society; IJOTCC = International Journal of Offender Therapy and Comparative Criminology.

${ }^{\mathrm{a}}$ Percentage of total legal articles (published by all journals) which are published by this journal. ${ }^{\mathrm{b}}$ Percentage of journal's articles which are legal articles. 


\section{Figures}

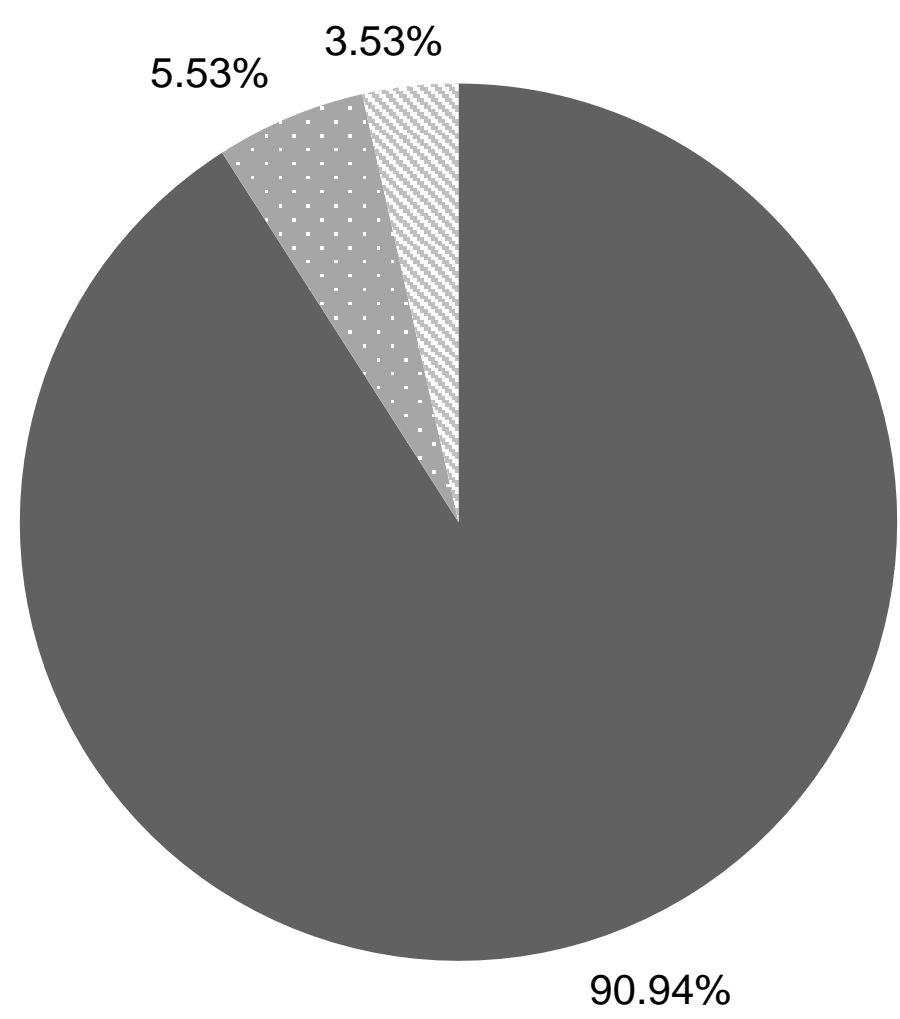

- \% Other Articles $\quad \%$ Courts \& Sentencing Articles $\$ \%$ Legal Articles

Figure 1. Percentage of articles published which are legal articles, courts and sentencing articles, and other articles. 


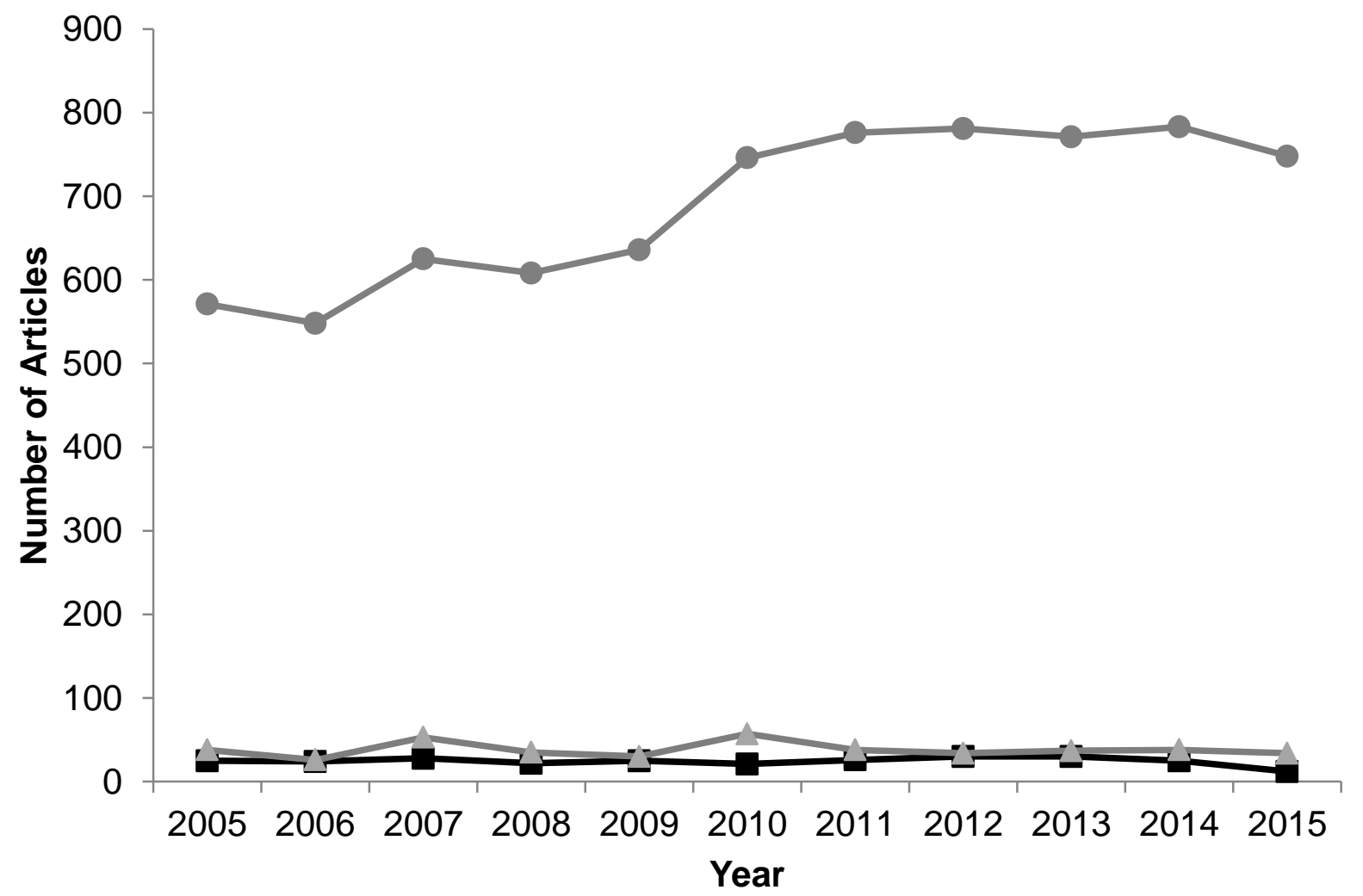

$\rightarrow-$ All Articles $\rightarrow$-Legal Articles $\rightarrow$ Courts and Sentencing Articles

Figure 2. Comparison of trends in number of all articles, number of legal articles, and number of courts and sentencing articles published over time. 


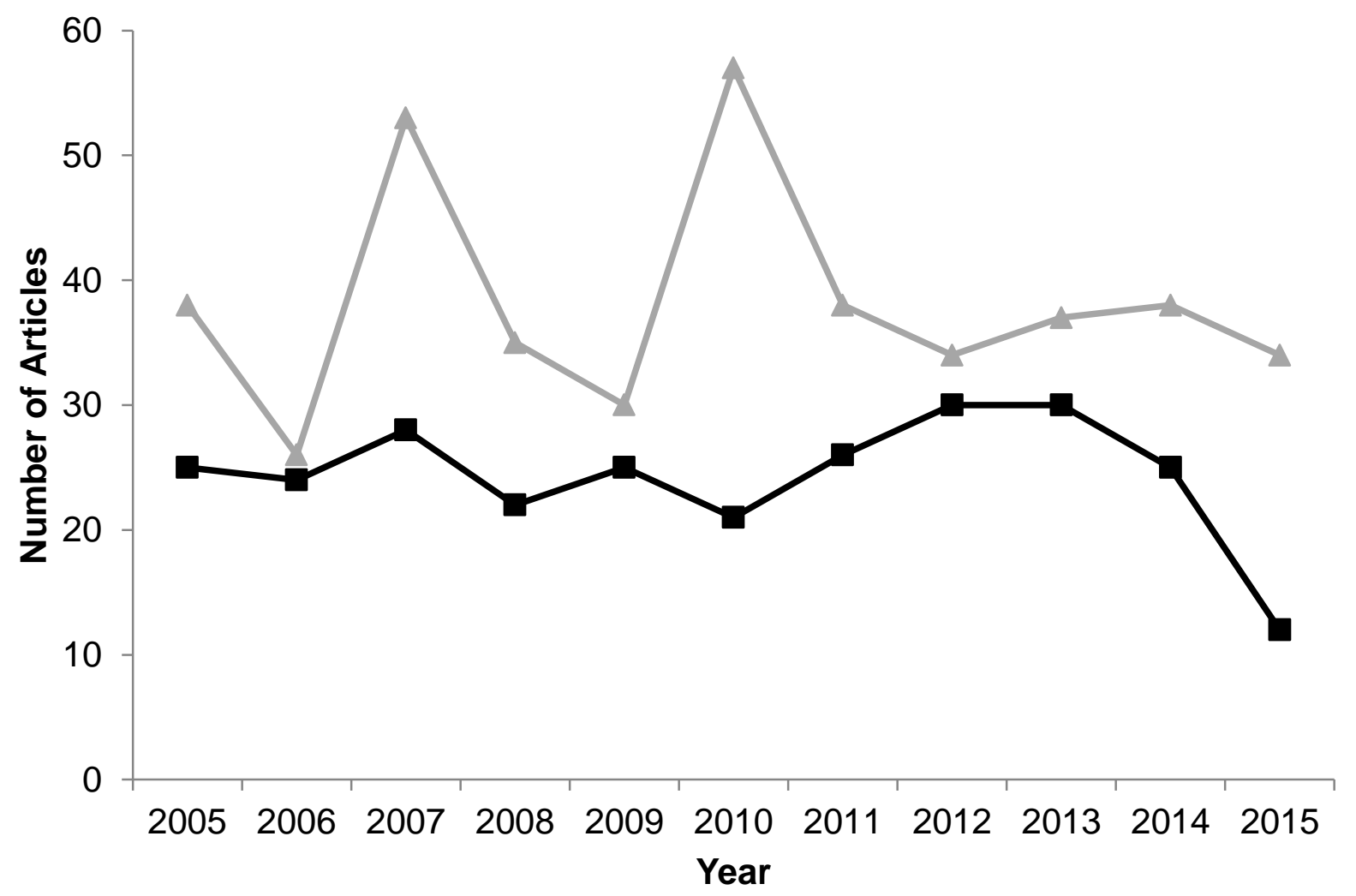

$\rightarrow$-Legal Articles $\quad-$ Courts and Sentencing Articles

Figure 3. Comparison of trends in number of legal articles and number of courts and sentencing articles published over time. 


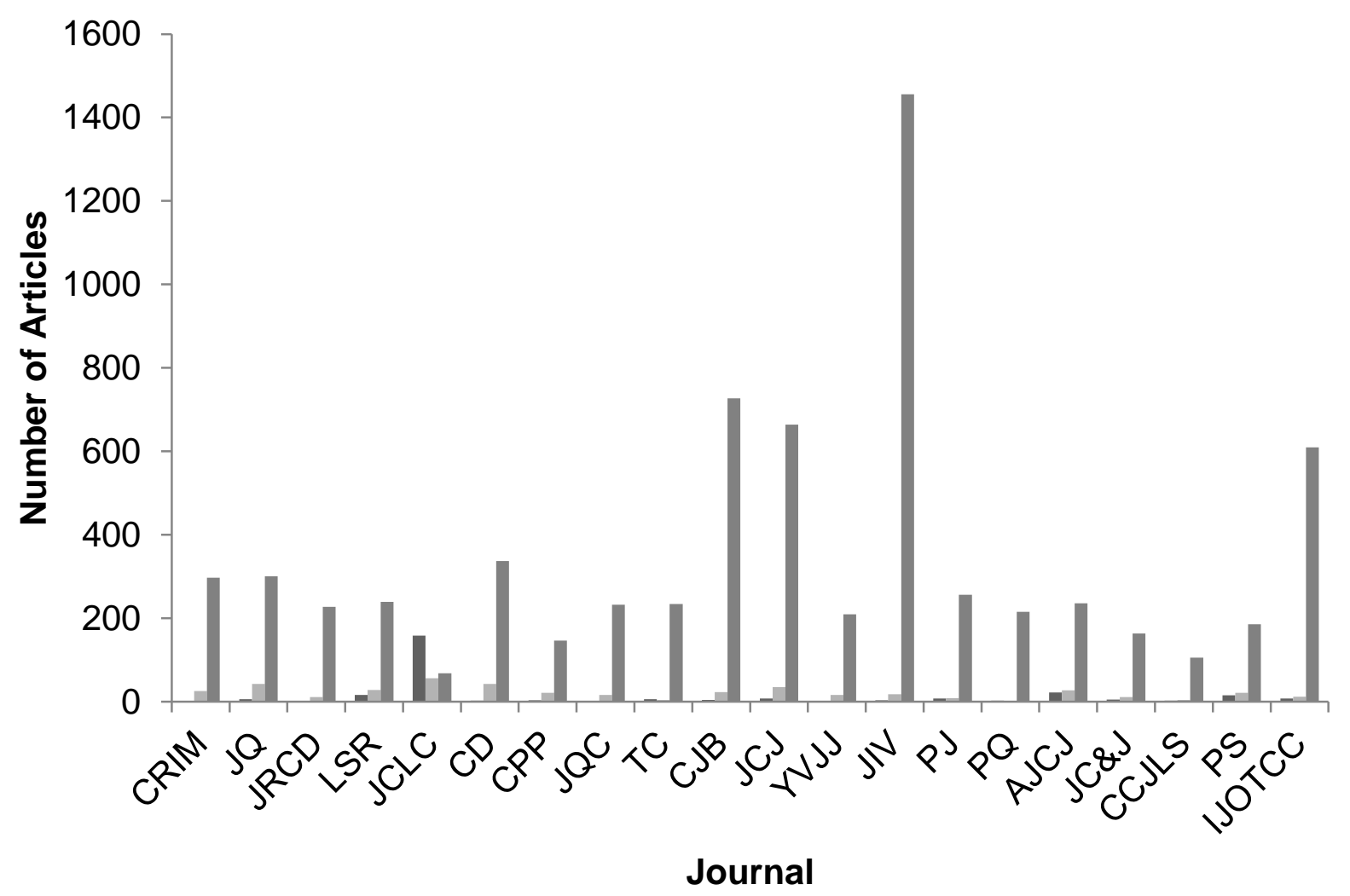

\section{- Legal Articles $\quad$ Courts and Sentencing Articles $\quad$ Other Articles}

Figure 4. Number of legal articles, number of courts and sentencing articles, and number of other articles published by journal. CRIM $=$ Criminology; JQ $=$ Justice Quarterly; JRCD $=$ Journal of Research in Crime and Delinquency; LSR = Law and Society Review; JCLC = Journal of Criminal Law and Criminology $; \mathrm{CD}=$ Crime and Delinquency $\mathrm{CPP}=$ Criminology and Public Policy; $\mathrm{JQC}=$ Journal of Quantitative Criminology; $\mathrm{TC}=$ Theoretical Criminology; $\mathrm{CJB}=$ Criminal Justice and Behavior $; \mathrm{JCJ}=$ Journal of Criminal Justice; YVJJ = Youth Violence and Juvenile Justice; JIV = Journal of Interpersonal Violence $; \mathrm{PJ}=$ Prison Journal $; \mathrm{PQ}=$ Police Quarterly; AJCJ = American Journal of Criminal Justice; $\mathrm{JC} \& \mathrm{~J}=$ Journal of Crime and Justice; CCJLS = Criminology, Criminal Justice, Law \& Society (formerly Western Criminology Review); PS = Punishment \& Society; IJOTCC = International Journal of Offender Therapy and Comparative Criminology. 


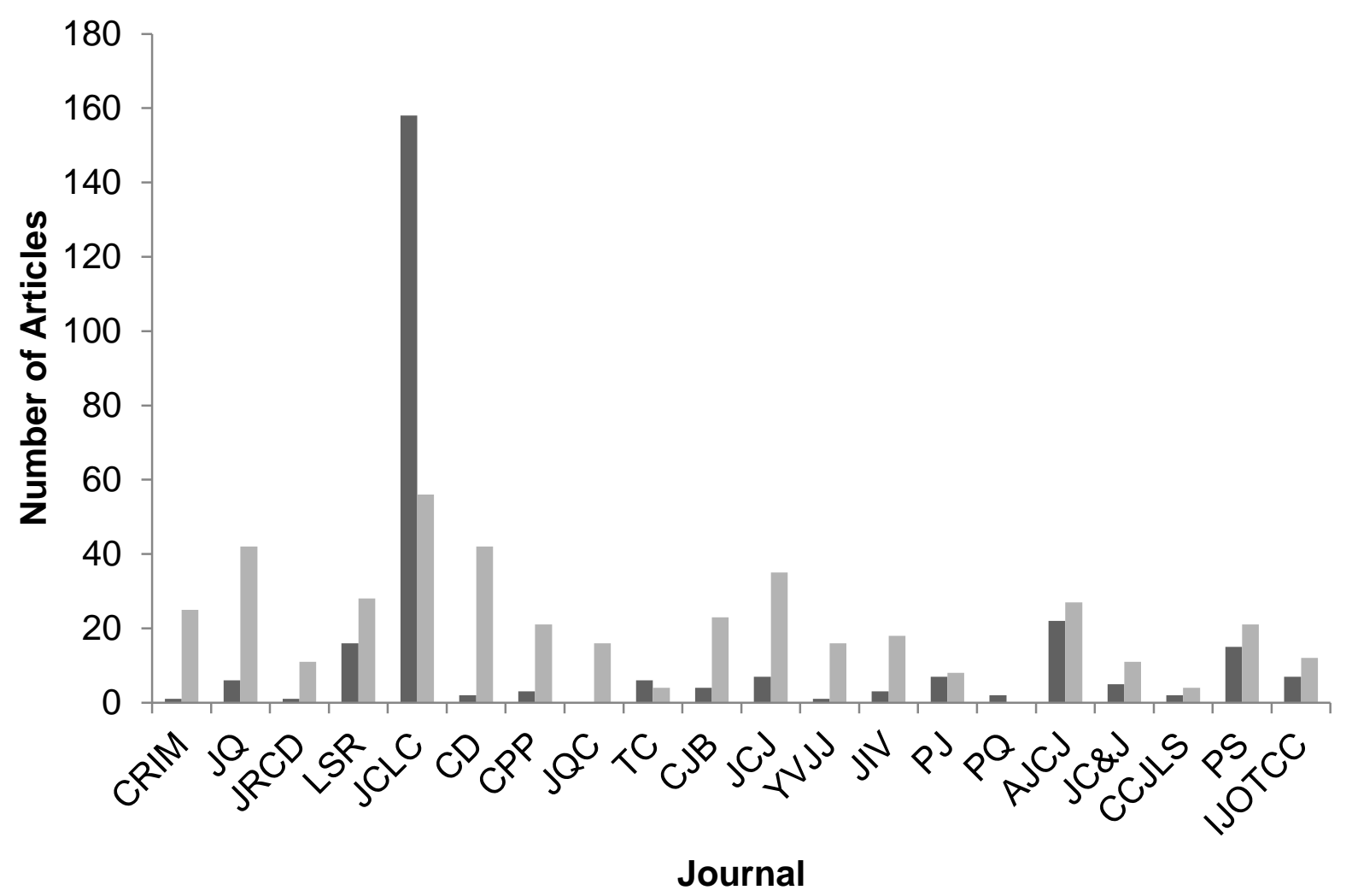

\section{- Legal Articles $\quad$ Courts and Sentencing Articles}

Figure 5. Number of legal articles and number of courts and sentencing articles published by journal. $\mathrm{CRIM}=$ Criminology $; \mathrm{JQ}=$ Justice Quarterly $\mathrm{JRCD}=$ Journal of Research in Crime and Delinquency; $\mathrm{LSR}=$ Law and Society Review $; \mathrm{JCLC}=$ Journal of Criminal Law and Criminology $; \mathrm{CD}=$ Crime and Delinquency; $\mathrm{CPP}=$ Criminology and Public Policy; $\mathrm{JQC}=$ Journal of Quantitative Criminology; $\mathrm{TC}=$ Theoretical Criminology; CJB = Criminal Justice and Behavior; JCJ = Journal of Criminal Justice; YVJJ $=$ Youth Violence and Juvenile Justice $; \mathrm{JIV}=$ Journal of Interpersonal Violence; PJ = Prison Journal $; \mathrm{PQ}$ $=$ Police Quarterly; AJCJ = American Journal of Criminal Justice $; \mathrm{JC} \& \mathrm{~J}=$ Journal of Crime and Justice; CCJLS = Criminology, Criminal Justice, Law \& Society (formerly Western Criminology Review); PS = Punishment \& Society; IJOTCC = International Journal of Offender Therapy and Comparative Criminology. 


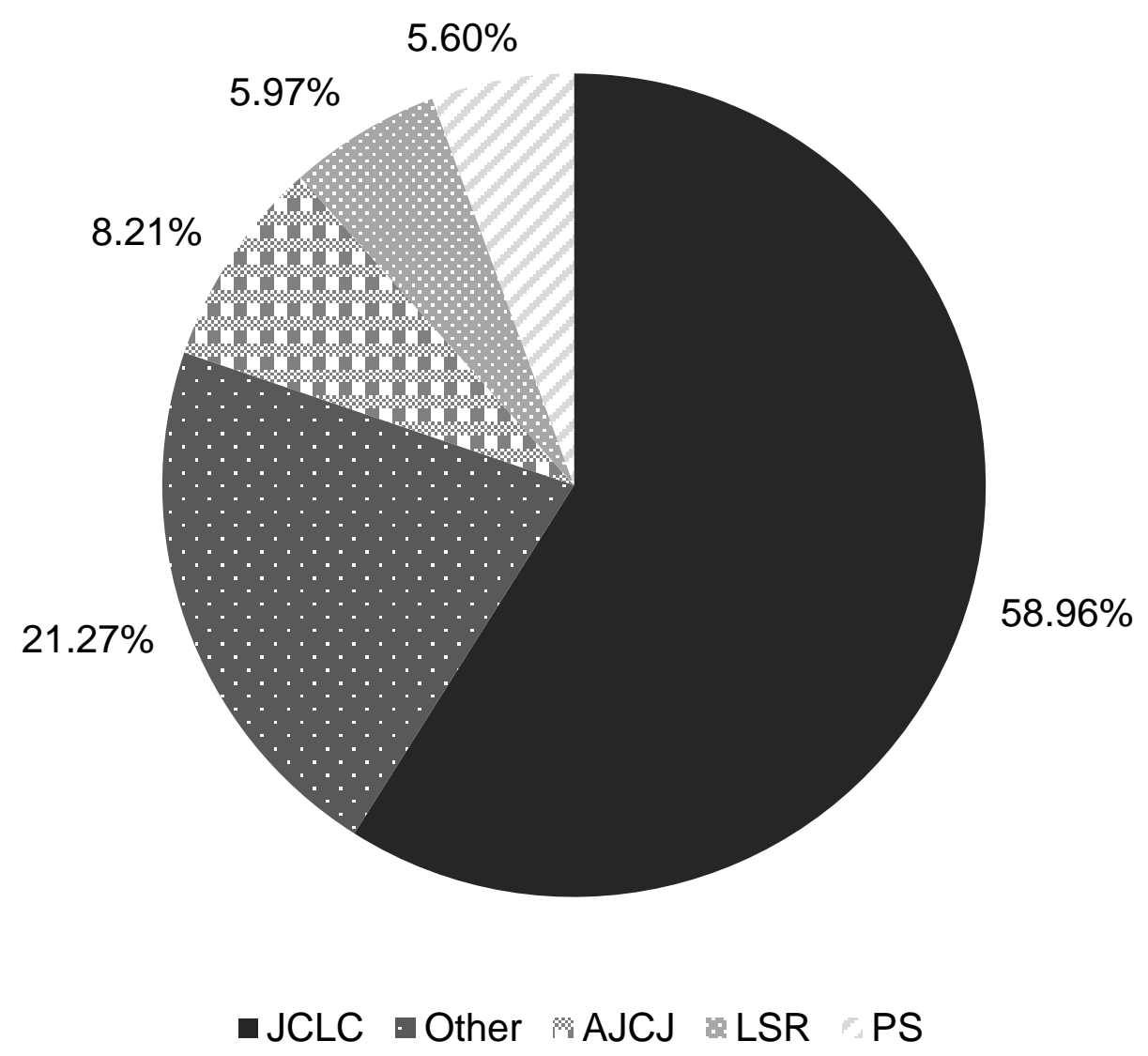

Figure 6. Percentage of total legal articles published by each journal. JCLC = Journal of Criminal Law and Criminology; AJCJ = American Journal of Criminal Justice; LSR = Law and Society Review; PS = Punishment \& Society. 


\section{Appendix A}

\begin{tabular}{|c|c|c|c|c|c|}
\hline Article & $\begin{array}{l}\text { Authors, } \\
\text { Journal }\end{array}$ & $\begin{array}{l}\text { Courts/ } \\
\text { Sentencing }\end{array}$ & Legal & $\begin{array}{l}\text { Neither } \\
\text { (Excluded) }\end{array}$ & Why? \\
\hline $\begin{array}{l}\text { Splitting the } \\
\text { Difference: } \\
\text { Modeling } \\
\text { Appellate Court } \\
\text { Decisions with } \\
\text { Mixed Outcomes }\end{array}$ & $\begin{array}{l}\text { Lindquist, } \\
\text { Martinek, } \\
\text { and } \\
\text { Hettinger } \\
\text { Law and } \\
\text { Society } \\
\text { Review, } \\
39(3)\end{array}$ & No & No & Yes & $\begin{array}{l}\text { While this article examines the law } \\
\text { indirectly and courts directly, } \\
\text { especially judicial discretion, it is } \\
\text { solely focused on establishing } \\
\text { theoretical propositions for panel } \\
\text { decision-making in cases with } \\
\text { mixed outcomes. It has no focus on } \\
\text { the criminal justice system, } \\
\text { criminal courts, or even } \\
\text { sentencing, and lacks any analysis } \\
\text { of the law. }\end{array}$ \\
\hline $\begin{array}{l}\text { Collegial } \\
\text { Influence and } \\
\text { Judicial Voting } \\
\text { Change: The } \\
\text { Effect of } \\
\text { Membership } \\
\text { Change on U.S. } \\
\text { Supreme Court } \\
\text { Justices }\end{array}$ & $\begin{array}{l}\text { Meinke \& } \\
\text { Scott, Law } \\
\text { and } \\
\text { Society } \\
\text { Review, } \\
\text { 41(4) }\end{array}$ & No & Yes & & $\begin{array}{l}\text { The primary focus of the article is } \\
\text { how judges vote following } \\
\text { structural changes to court } \\
\text { membership on search and seizure } \\
\text { cases after Mapp v. Ohio in cases } \\
\text { concerning the progeny of } \\
\text { Miranda v. Arizona. Thus, these } \\
\text { cases do focus on both judicial } \\
\text { discretion and the law, and it } \\
\text { seems the primary focus is on } \\
\text { judicial decision-making. } \\
\text { However, the article is more } \\
\text { concerned with voting patterns } \\
\text { concerning criminal procedure } \\
\text { after two landmark cases. Hence, it } \\
\text { can be argued that it is also } \\
\text { primarily concerned with the } \\
\text { impact of the law. Since the } \\
\text { authors examine legal cases, and } \\
\text { construct indicators of issues } \\
\text { inherent in both search and seizure } \\
\text { and Fifth Amendment cases, the } \\
\text { article then becomes legal in } \\
\text { nature. Also, the authors have to } \\
\text { examine dozens of Supreme Court } \\
\text { cases in order to construct } \\
\text { indicators and examine the effect } \\
\text { of panel composition on voting. } \\
\text { Moreover, cases concerning } \\
\text { judicial discretion are traditionally } \\
\text { focused on sentencing and criminal } \\
\text { courts behavior; not the Supreme } \\
\text { Court's decisions in the review of } \\
\text { criminal procedure cases. }\end{array}$ \\
\hline
\end{tabular}




\begin{tabular}{|c|c|c|c|c|c|}
\hline $\begin{array}{l}\text { The } \\
\text { Heterogeneous } \\
\text { State and Legal } \\
\text { Pluralism in } \\
\text { Mozambique }\end{array}$ & $\begin{array}{l}\text { Boventura } \\
\text { de Sousa } \\
\text { Santos, } \\
\text { Law and } \\
\text { Society } \\
\text { Review } \\
40(1)\end{array}$ & Yes & No & & $\begin{array}{l}\text { This article had little to no relation } \\
\text { to either criminal justice or } \\
\text { criminology. However, the article } \\
\text { is focused on legal pluralism and } \\
\text { administration by the state by } \\
\text { examining community courts and } \\
\text { traditional authorities. The article } \\
\text { explains and examines the purpose } \\
\text { and structure of the court system } \\
\text { within Mozambique. Furthermore, } \\
\text { the article relies on "empirical data } \\
\text { more directly relevant for the } \\
\text { analysis undertaken here comprise } \\
\text { extensive research focused on } 34 \\
\text { community courts and } 23 \\
\text { traditional authorities, located in } \\
\text { six of the country's } 11 \text { provinces" } \\
\text { (p. } 41 \text { ). This is an article we chose } \\
\text { to include because it can be argued } \\
\text { that it relates to courts and their } \\
\text { purpose in light of political and } \\
\text { cultural forces. }\end{array}$ \\
\hline $\begin{array}{l}\text { Friends of the } \\
\text { Court: The } \\
\text { Republican } \\
\text { Alliance and } \\
\text { Selective Activism } \\
\text { of the } \\
\text { Constitutional } \\
\text { Court of Turkey }\end{array}$ & $\begin{array}{l}\text { Belge, } \\
\text { Law and } \\
\text { Society } \\
\text { Review, } \\
40(3)\end{array}$ & No & Yes & & $\begin{array}{l}\text { This article is also complex, but } \\
\text { even though it focuses on judicial } \\
\text { power and independence, the } \\
\text { primary focus is on examining } \\
\text { human rights cases in Turkey in } \\
\text { order to discuss judicial power. } \\
\text { While judicial power and the } \\
\text { Constitutional Court could render } \\
\text { this article as a courts and } \\
\text { sentencing article, the authors drew } \\
\text { on the criminal code, international } \\
\text { human rights law, and dozens of } \\
\text { Constitutional Court cases to } \\
\text { examine in their analysis. } \\
\text { Moreover, the article reads more } \\
\text { like a content or doctrinal analysis } \\
\text { of the Court itself. Thus, even } \\
\text { though it focuses on the activism } \\
\text { of the Court, which implies both } \\
\text { courts and judicial decision- } \\
\text { making, the article relies on legal } \\
\text { analysis via examining the law, } \\
\text { civil rights and liberties, and Court } \\
\text { cases. }\end{array}$ \\
\hline $\begin{array}{l}\text { The Influence of } \\
\text { Jurisprudential } \\
\text { Considerations } \\
\text { on Supreme }\end{array}$ & $\begin{array}{l}\text { Lindquist } \\
\text { and Klein, } \\
\text { Law and } \\
\text { Society }\end{array}$ & No & No & Yes & $\begin{array}{l}\text { While this article does focus on } \\
\text { courts (U.S. Supreme Court), } \\
\text { judicial decision making, and legal } \\
\text { reasoning analysis, it has no }\end{array}$ \\
\hline
\end{tabular}




\begin{tabular}{|c|c|c|c|c|}
\hline $\begin{array}{l}\text { Court } \\
\text { Decisionmaking: } \\
\text { A Study of } \\
\text { Conflict Cases }\end{array}$ & $\begin{array}{l}\text { Review } \\
40(1) .\end{array}$ & & & $\begin{array}{l}\text { relation to the criminal justice } \\
\text { system. Consider the following: } \\
\text { "Our aim in this article is to test } \\
\text { the proposition that justices' voting } \\
\text { behavior is influenced by their } \\
\text { desire to reach legally sound } \\
\text { decisions. To do so, we examine } \\
\text { cases in which the Court resolved } \\
\text { an intercircuit conflict by choosing } \\
\text { the legal rule favored by one set of } \\
\text { circuit courts over that favored by } \\
\text { another. } \\
\text { Since the over-whelming majority } \\
\text { of conflicts involve only two } \\
\text { viable legal positions, we treat the } \\
\text { Supreme Court's decision as a } \\
\text { choice between } \\
\text { two teams" (p. 141). This article } \\
\text { really only focused on appellate } \\
\text { decision-making and court } \\
\text { dynamics, but makes no implicit or } \\
\text { explicit connection to criminal } \\
\text { courts, or the criminal justice } \\
\text { system. As opposed to the article } \\
\text { above that discusses community } \\
\text { courts and legal pluralism, this } \\
\text { article ostensibly does not have } \\
\text { any application to the criteria we } \\
\text { have set forth, as opposed to the } \\
\text { aforementioned article which can } \\
\text { be included as it focuses on the } \\
\text { structure and purpose of courts at } \\
\text { large, and does make some } \\
\text { connections to the criminal justice } \\
\text { system- both implicitly and } \\
\text { explicitly. }\end{array}$ \\
\hline $\begin{array}{l}\text { The "Liberation" } \\
\text { of Federal } \\
\text { Judges' } \\
\text { Discretion in the } \\
\text { Wake of the } \\
\text { Booker/Fanfan } \\
\text { Decision: Is } \\
\text { There Increased } \\
\text { Disparity and } \\
\text { Divergence } \\
\text { between Courts? }\end{array}$ & $\begin{array}{l}\text { Ulmer, } \\
\text { Lighty, } \\
\text { and } \\
\text { Kramer, } \\
\text { Justice } \\
\text { Quarterly, } \\
28(6)\end{array}$ & Yes & No & $\begin{array}{l}\text { This article focuses on disparity in } \\
\text { criminal sentencing following the } \\
\text { enactment of legislation in the } \\
\text { early } 2000 \text { s and following United } \\
\text { States v. Booker and its progeny. } \\
\text { Again, this is similar to the } \\
\text { Meineke and Scott article in that } \\
\text { both judicial discretion and law } \\
\text { (i.e. courts and legal topics) are } \\
\text { intertwined. While this article does } \\
\text { focus on the impact of criminal } \\
\text { justice policy and Supreme Court } \\
\text { cases, the cases in question deal } \\
\text { directly with judicial discretion in }\end{array}$ \\
\hline
\end{tabular}




\begin{tabular}{|l|l|l|l|}
\hline & & & \\
& & $\begin{array}{l}\text { sentencing and appellate review of } \\
\text { criminal sentencing. Thus, even } \\
\text { though there is a legal component, } \\
\text { this article does not examine those } \\
\text { decisions or subsequent cases, but } \\
\text { instead focuses on disparity in } \\
\text { criminal sentencing following } \\
\text { those decisions. Overall, this } \\
\text { article, while complex, is primarily } \\
\text { focused on criminal courts and } \\
\text { judicial discretion at large. }\end{array}$ \\
\hline
\end{tabular}

